\title{
Plantar pressure distribution evaluation in children with down syndrome from 2 to 5 years old
}

\author{
Avaliação da distribuição das pressões plantares em \\ crianças com síndrome de down entre 2 e 5 anos
}

Evaluación de la distribución de las presiones plantares en niños con síndrome de down entre 2 y 5 años

Paula Silva de Carvalho Chagas $₫[$ [a], Riuraly Caroline Barreiros Fortunato Rangel $[$ [a], Sulamita Saile de Jesus Oliveira Dornelas ${ }^{[a]}$, Anderson Daibert Amaral ${ }^{[b]}$, Flávio Augusto Teixeira Ronzani@ [a], Érica Cesário Defilipo $『$ [c]*

[a] Universidade Federal de Juiz de Fora (UFJF), Juiz de Fora, MG, Brazil

[b] Instituto Brasileiro da Saúde do Movimento (IBSM), Juiz de Fora, MG, Brazil

[c] Universidade Federal de Juiz de Fora (UFJF), Governador Valadares, MG, Brazil

Abstract

Introduction: Some peculiar features of Down Syndrome (DS), such as ligament laxity, hypotonia, delay in gait acquisition, among others, may generate alterations in the distribution of plantar pressures, modifying

* PSCC: PhD, email: paula.chagas@ufjf.edu.br RCBFR: BS, email: riurallybarreiros@hotmail.com SSJOD: BS, email: sulamitasaile@gmail.com ADA: BS, email: anderson@ibsm.com.br FATR : MS, email: ronzani@terra.com.br ECD: Doctoral Student, email: erica.defilipo@ufjf.edu.br 
the plantar support. Objective: To verify whether there are differences in the evaluation of plantar pressure distributions in standing posture between the measurement instruments (Baropodometer, SAPO, and Radiography). Method: This was a cross-sectional study, evaluating ten children with SD and ten children with normal development (ND), aged from two to five years old. Bio-photogrammetry, baropodometry, and foot radiography were used to assess the plantar pressure distribution. Kappa analysis was used to evaluate the agreement index between the different instruments. Results: Children with DS and ND had a higher prevalence of pronated feet in all three instruments, with poor to substantial agreement among the instruments. Conclusion: According to this study instruments, there was a greater prevalence of pronated feet in the two groups. Differences in the evaluation of the distribution of plantar pressures in the standing posture between the Baropodometer, SAPO, and radiography were observed. These instruments should be used in a complementary manner, as they propose to evaluate different aspects of the feet alignment.

Keywords: Down Syndrome. Flat Foot. Preschoolers.

\section{Resumo}

Introdução: Algumas características peculiares da Síndrome de Down (SD), como a frouxidão ligamentar, hipotonia, atraso na aquisição da marcha, dentre outras, podem gerar alterações na distribuição das pressões plantares, modificando o apoio plantar. Objetivo: Verificar se existem diferenças na avaliação da distribuição das pressões plantares, na postura de pé, entre os instrumentos de mensuração Baropôdometro, SAPO e Radiografia. Método: Estudo transversal que avaliou dez crianças com SD e dez crianças com desenvolvimento normal (DN), com idade entre dois e cinco anos. Para avaliação da distribuição das pressões plantares foram utilizados a biofotogrametria, baropodometria e radiografia dos pés. Foi utilizado a análise Kappa para avaliar o índice de concordância entre os diferentes instrumentos. Resultados: As crianças com SD e DN apresentaram maior prevalência de pés pronados nos três instrumentos, havendo concordância de pobre a substancial entre os instrumentos. Conclusão: Houve maior prevalência de pés pronados nos dois grupos de acordo com os instrumentos utilizados neste estudo. Foram encontradas diferenças na avaliação da distribuição das pressões plantares na postura de pé entre o Baropôdometro, SAPO e Radiografia, devendo estes instrumentos serem usados de forma complementar, já que se propõem a avaliar aspectos distintos do alinhamento dos pés.

Palavras-chave: Síndrome de Down. Pé Chato. Pré-escolares.

\section{Resumen}

Introducción: Algunas características peculiares del Síndrome de Down (SD), como la flojedad ligada, hipotonía, retraso en la adquisición de la marcha, entre otras, pueden generar alteraciones en la distribución de las presiones plantares, modificando el apoyo plantar. Objetivo: Verificar si existen diferencias en la evaluación de la distribución de las presiones plantares, en la postura de pie, entre los instrumentos de medición Baropôdometro, SAPO y Radiografía. Método: Estudio transversal que evaluó diez niños con SD y diez niños con desarrollo normal (DN), con edad entre dos y cinco años. Para la evaluación de la distribución de las presiones plantares se utilizaron biofotogrametría, baropodometría y radiografía de los pies. Se utilizó el análisis Kappa para evaluar el índice de concordancia entre los diferentes instrumentos. Resultados: Los niños con SD y DN presentaron mayor prevalencia de pies pronados en los tres instrumentos, habiendo concordancia de pobre a sustancial entre los instrumentos Conclusión: Hubo una mayor prevalencia de pies pronados en los dos grupos de acuerdo con los instrumentos utilizados en este estudio. Se encontraron diferencias en la evaluación de la distribución de las presiones plantares en la postura de pie entre el Baropôdometro, SAPO y Radiografía, debiendo estos instrumentos ser utilizados de forma complementaria, ya que se proponen a evaluar aspectos distintos de la alineación de los pies.

Palabras clave: Sindrome de Down. Pie Chato. Preescolares. 


\section{Introduction}

Down syndrome (DS) is due to genetic alterations involving the chromosome 21 , characterized by the existence of an extra, total or partial copy of its genetic material [1], resulting in particular physical and mental disorders. In Brazil, this is the most common genetic syndrome, with an incidence of 1 in 600 live births, and the number of newborns with DS reaches about 8 thousand a year [2].

Individuals affected by DS present a delay in the neuropsychomotor development, slow physical growth, hypotonia, ligament laxity and delay in gait acquisition, generating alterations in the distribution of the plantar pressures, modifying the plantar support $[3,4]$. These changes may be related to flat foot, characterized by plantar arch collapse, and are usually associated with the muscular weakness and hypotonia frequently present and closely related to this syndrome, which justifies the higher prevalence of flat feet in children with DS [4].

A complete evaluation of the child with DS is known to be of paramount importance. When performing a clinical evaluation of the feet, one can intervene early and adopt preventive measures that may decrease joint and muscle imbalances, as well as their possible negative consequences for biomechanical alignment [5]. Therefore, one needs to know in detail the type of plantar pressure distribution and the plantar support of children with DS, as well as to define the best measuring instrument for this purpose, in order to verify the need and the type of orthosis and / or insole more indicated for such clientele. Some measuring instruments are commonly used in the clinical practice. The X-ray has been used for the medical diagnosis of flat foot [6]. In the clinical routine of the physical therapist, postural assessment of foot alignment through photos [7] and evaluation of plantar pressure distribution through baropodometry [8-10] is often performed. There is still no consensus in the literature as to the ideal method for measuring foot alignment in the clinical setting [11].

The objective of this study was to verify if there are differences in the evaluation of plantar pressure distributions in standing posture between different measurement instruments, both in children with DS as in children with normal development (ND), in the age group from two to five years.

\section{Methods}

Cross-sectional study, approved by the Research Ethics Committee under opinion number 264,071. Parents and guardians of children, after being aware of the study intentions and the methods used, signed an Informed Consent Form. The evaluations were carried out at the University Hospital of the city.

The sample consisted of 10 children diagnosed with DS and 10 children with ND, aged between two and five years old, who had independent gait without associated neurological dysfunctions or other factors that could alter gait pattern. In a convenience sample, children with ND were matched with children with DS in relation to age and sex. Such measure was necessary due to the absence of normative data for the evaluation of plantar pressure distributions in children with DS.

Evaluations were performed first in children with DS, and the same procedures were later performed in children with ND. Initially, one of the evaluators collected information on the children identification and data, such as: name, gender, age, race, anthropometric measures (weight, height, body mass index and shoe size), and age of gait acquisition reported by parents.

Next, the same evaluator assessed the distribution of foot pressures in different foot postures using a Baropodometer (Arkipelago brand) with Footwork ${ }^{\circledR}$ software, as follows: with the child seated, the feet were painted with stamping ink and the child walked on two sheets of brown paper, until the end of the last sheet. Then, the brown paper with the child's last plantar impression was placed on the Baropodometer platform and the child stood in static position above the mark of its feet, with the upper limbs at the side of the body, looking at a fixed point in the wall for the minimum time of 6 seconds. The feet were impressed on brown paper to facilitate the evaluation, serving as a template for postural assessment between the different instruments.

Reports obtained by the Footwork ${ }^{\circledR}$ software were printed and analyzed to define the children's type of foot. For this analysis, plantar impressions were used, in which lines were drawn to identify the anatomical regions of the foot. Initially, the midpoint of the hindfoot was identified and a longitudinal line was drawn up to the forefoot, in the direction of the second interdigit (L1). Then, using a conventional ruler, two lines were drawn parallel to L1, one of which touched 
the lateral border (L2) and the other the medial border (L3) of the foot. In the forefoot, a horizontal line (L4) was drawn between L2 and L3. The distance between L2 and L3 in the forefoot corresponds to its width in centimeters (L4). Subsequently, a horizontal line (L5) was drawn at the midpoint between L2 and
L3, which corresponds to the midfoot width [12]. From this analysis, a foot was considered normal when the midfoot width (L5) corresponded to $1 / 3$ of the forefoot (L4); when such width was greater than $1 / 3$ of the forefoot measurement, the foot was considered to be pronated (Figure 1).

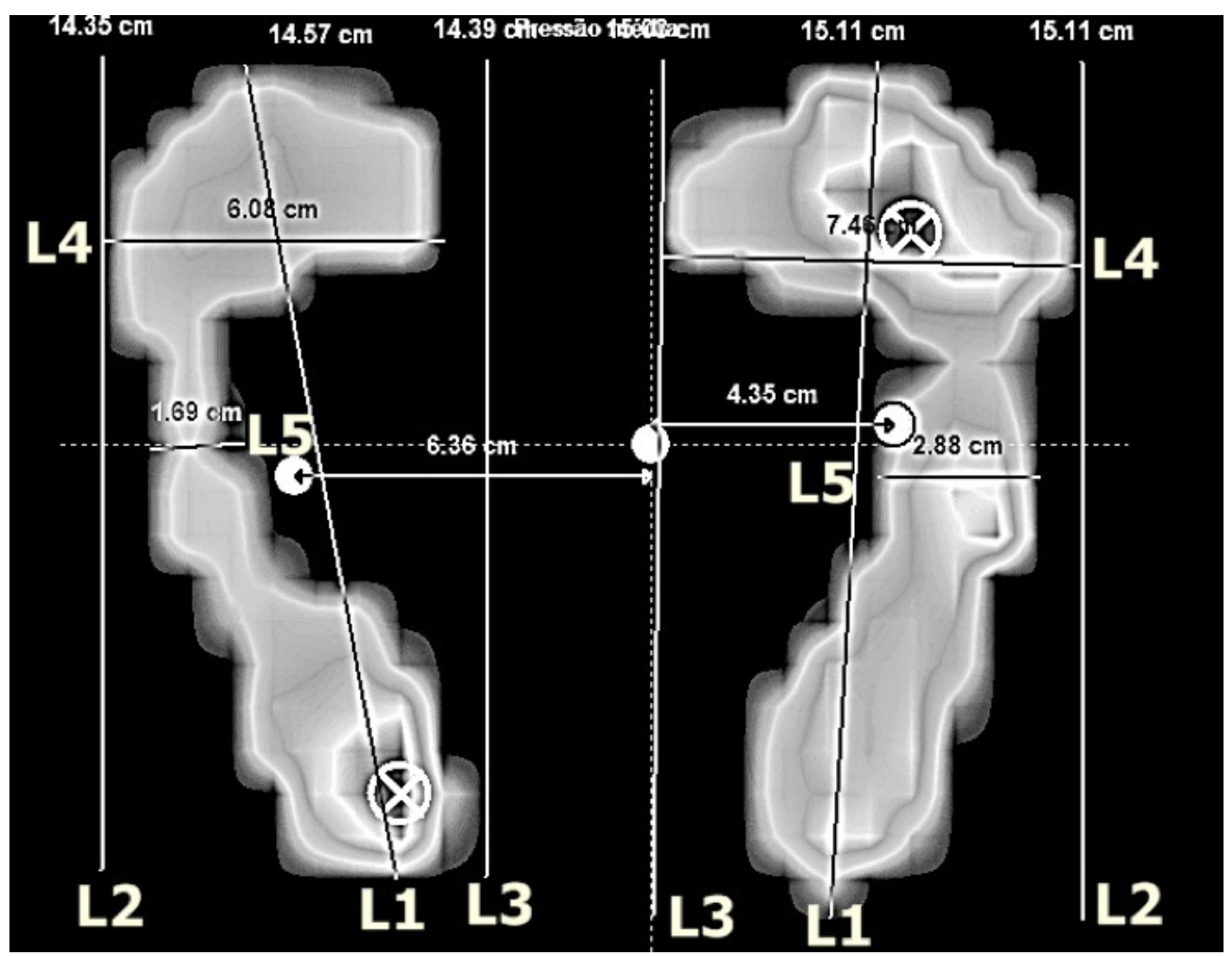

Figure 1 - Representative figure of the plantar pressure evaluation made with the Baropodometer by FootWork ${ }^{\circledR}$ software.

Then, another researcher evaluated the child's type of foot using the Software for Postural Evaluation (SAPO), through bio-photogrammetry, which is based on image digitalization [7]. To carry out this procedure, a plumb line was attached to the ceiling and placed with two polystyrene balls spaced 1 meter from each other, glued on the wire for later calibration of the image. The children were positioned so theyit and the plumb line were in the same perpendicular plane to the axis of the digital still camera $\left(\mathrm{Nikon}^{\circledR}\right.$, 5.0 megapixels), which was placed 3 meters away and supported on a tripod at a height corresponding to about half the child's height. They were photographed in the front and back postures, right and left profile, being oriented to be static on the same mark of their feet in the sheet of brown paper used in the first evaluation. The bone references that guided the angular calculations were marked with Styrofoam glued to a felt base for better fixation in the following anatomical points according to SAPO protocol: lateral malleoli, medial malleoli, bilateral calcaneal tendon, intermalleolar line, the region between the second and third metatarsus and fifth metatarsus. The photographs were transferred to the computer for the photogrammetric analysis of the feet. Through the SAPO analysis, the feet were classified as pronated or normal. The angle used for such a definition was named prone-supine angle, obtained by photography in posterior view, with bone markers on the calcaneus tendon and the other on the point between the posterior malleolus. To classify the right foot as pronated, this angle had to be greater than $90^{\circ}$. In the left foot, if the angle was smaller than $90^{\circ}$, it was considered to be pronated. In both the right and left foot, when this angle is the exact value of $90^{\circ}$ the foot was classified as normal (Figure 2). 


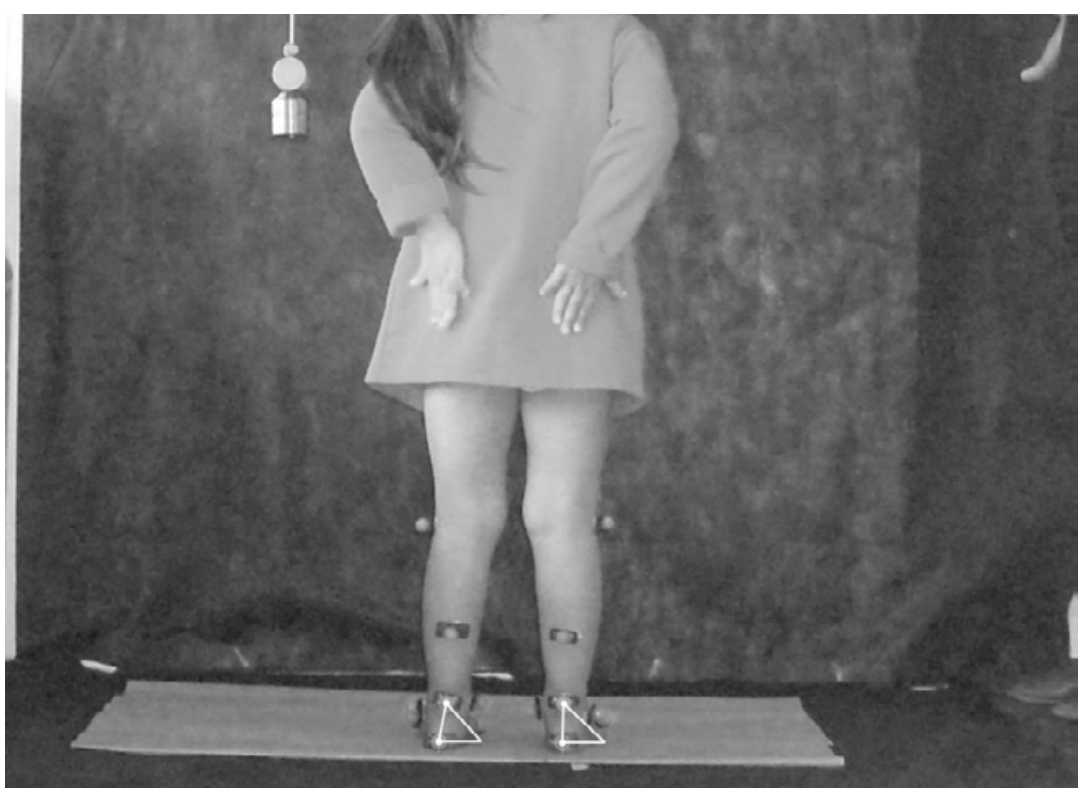

Figure 2 - Representative figure of the prone-supine angle evaluation through the SAPO software.

After this stage, the child was referred to the hospital imaging sector for a radiography in the orthostatic position, with load at a standard focusfilm distance of $1 \mathrm{~m}$, following the guidelines cited in the Guidelines on Best Practice in the X-Ray Imaging of Children [6]. No sedative method was used and the children were taken care by the caregivers, when necessary. To define the foot type according to the radiographic analysis, the radiographic parameters used were focused on the relation of the angle formed between the lower edge of the calcaneus and the ground (calcaneus inclination angle). Angles from $20^{\circ}$ to $30^{\circ}$ were regarded as a reference value for classifying the foot as normal; values smaller than $20^{\circ}$ meant the foot was classified as pronated [5] (Figure 3).

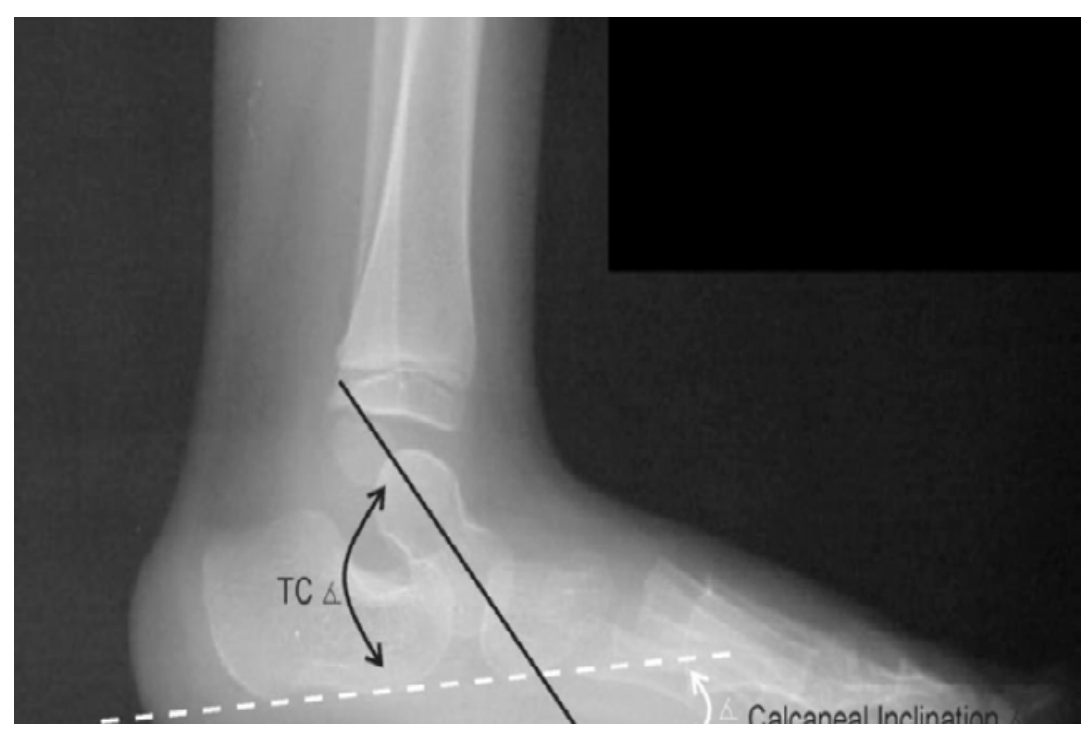

Note: The normal midfoot line has to go pass the first metatarsus. Black color line $=$ midfoot line. $\operatorname{Tc} \Delta=$ talocalcaneal angle. $\Lambda$ = calcaneal angle of inclination.

Figure 3 - Representative figure of lateral radiography of the feet, angle and gait for evaluation and documentation of the degree of feet abnormalities by the $x$-ray. 
This study had three blind evaluators (one for each instrument), who only knew the results of each evaluation at the end of the analyses.

Statistical analysis

Normality analysis was performed for descriptive variables using the Shapiro-Wilk test, to verify whether the sample fit a normal curve. As the sample presented a normal distribution for all descriptive variables, we chose to use parametric tests, with Student's t-test, for comparison between groups. The prevalence of pronated feet was calculated according to each instrument used. The Kappa test verified the agreement between the classification of the defined foot types for children (normal or pronated) among the measuring instruments as follows: $<0$ for lack of agreement; 0-0.19 poor agreement; $0.20-0.39$ weak agreement; $0.40-0.59$ moderate agreement; $0.60-0.79$ substantial agreement, and 0.80-1.00 almost perfect agreement [13].

The Statistical Package for Social Sciences (SPSS ${ }^{\circledR}$, v. 15.0, 2007) was used in all statistical analyzes, considering the level of significance $\alpha=0.05$.

\section{Results}

This study had the participation of 20 children, of which ten had a diagnosis of SD, with a mean age of 53.20 months ( $S D=13.98)$, and ten with a mean age of 59.50 months (SD $=11,64)$, matched according to gender (50\% female and 50\% male) and age, with no statistical differences between groups in these characteristics $(p>0.05)$.

Children in the DS group had significantly lower stature, weight, shoe size, and foot size than children in the ND group $(\mathrm{p}<0.05)$. In addition, in children in the DS group, the age of gait acquisition was higher when compared to children in the ND group, according to parents' reports. In addition, there was no significant difference ( $p>0.05)$ for BMI between groups (Table 1).

Table 1 - Mean Scores and standard deviation obtained for descriptive variables in the t-test, between groups DS and ND

\begin{tabular}{|c|c|c|c|}
\hline \multirow[t]{2}{*}{ Descriptive Variables } & \multicolumn{2}{|c|}{ Groups } & \multirow[t]{2}{*}{$\mathrm{p}$} \\
\hline & ND & DS & \\
\hline Height & $1.11(0.08)$ & $0.99(0.07)$ & $0.004^{*}$ \\
\hline Weight & $20.24(3.60)$ & $16.83(2.30)$ & $0.021^{*}$ \\
\hline
\end{tabular}

(To be continued)
(Conclusion)

\begin{tabular}{lccc}
\hline Descriptive Variables & \multicolumn{2}{c}{ Groups } & p \\
\hline & ND & DS & \\
\hline Body Mass Index (BMI) & $16.36(1.31)$ & $17.08(1.59)$ & 0.283 \\
\hline Gait Acquisition Age & $12.45(1.77)$ & $22.70(4.88)$ & $0.001^{*}$ \\
Shoe Size & $28.30(2.05)$ & $24.70(1.25)$ & $0.001^{*}$ \\
R Foot Size (cm) & $14.26(1.18)$ & $11.84(1.48)$ & $0.001^{*}$ \\
L Foot Size (cm) & $14.17(1.08)$ & $11.73(1.48)$ & $0.001^{*}$ \\
\hline
\end{tabular}

Note: $\mathrm{ND}=$ normal development; $\mathrm{DS}=$ Down Syndrome; $R=$ right; $L=$ left. * $p<0.05$ represent significant differences. Values represented as means, with the standard deviation (SD) between parentheses.

According to the assessment instruments used, most participants in the ND and DS groups had pronated feet when classified by SAPO and radiography, and the DS group also presented a higher prevalence of pronated feet classified by the Baropodometer (Table 2).

Table 2 - Types of foot defined by Baropodometer, SAPO, and $\mathrm{X}$-ray, demonstrated by frequency (percentage between parentheses)

\begin{tabular}{lccccc}
\hline \multirow{2}{*}{ Types of feet } & \multirow{2}{*}{ Side } & \multicolumn{2}{c}{ Group DS } & \multicolumn{2}{c}{ Group ND } \\
\cline { 3 - 6 } & & Normal & Pronated & Normal & Pronated \\
\hline \multirow{2}{*}{ Baropodometer } & R & $1(10 \%)$ & $9(90 \%)$ & $7(70 \%)$ & $3(30 \%)$ \\
& SAPO & $1(10 \%)$ & $9(90 \%)$ & $8(80 \%)$ & $2(20 \%)$ \\
& R & $4(40 \%)$ & $6(60 \%)$ & $3(30 \%)$ & $7(70 \%)$ \\
X-ray & L & $3(30 \%)$ & $7(70 \%)$ & $4(40 \%)$ & $6(60 \%)$ \\
& R & $2(20 \%)$ & $8(80 \%)$ & $2(20 \%)$ & $8(80 \%)$ \\
\hline
\end{tabular}

Note: $\mathrm{ND}=$ normal development; $\mathrm{DS}=$ Down Syndrome; $\mathrm{R}=$ right; $\mathrm{L}=$ left.

For the ND group, according to the Kappa, in the analysis of the agreement between the instruments SAPO and Baropodometer, there was no agreement between the classifications of foot types $(\mathrm{k}=-0.034$; $\mathrm{p}=0.880$ and $\mathrm{k}=-0.429 ; \mathrm{p}=0.053$ for the right and left feet, respectively). In the Baropodometer and Radiography analysis, there was a poor agreement between the classifications of foot types $(\mathrm{k}=0.194$, $\mathrm{p}=0.301$ and $\mathrm{k}=0.054, \mathrm{p}=0.598$ for the right and left feet, respectively). In the analysis between SAPO and Radiography, there was a weak agreement $(\mathrm{k}=0.211$, $\mathrm{p}=0.490$, and $\mathrm{k}=0.286, \mathrm{p}=0.197$ for the right and left feet, respectively). 
However, for the DS group, according to Kappa, in the agreement analysis between the SAPO and Baropodometer instruments, there was a weak to moderate agreement between the classifications of foot types $(\mathrm{k}=0.286, \mathrm{p}=0.197$ and $\mathrm{k}=0.412$, $\mathrm{p}=0.107$ for the right and left feet, respectively). In the analysis between the Baropodometer and Radiography, there was a substantial agreement between the classification of foot types ( $\mathrm{k}=0.615$, $p=0.035$; for both feet). In the analysis between SAPO and Radiography, there was a moderate to substantial concordance $(\mathrm{k}=0.545, \mathrm{p}=0.053$, and $\mathrm{k}=0.737$, $\mathrm{p}=0.016$ for the right and left feet, respectively).

\section{Discussion}

The study results show that most children with DS and ND presented pronated feet according to SAPO and Radiography instruments. For the group with ND, the instruments showed no agreement or weak agreement between foot classifications, and for the group with DS, the agreement presented by the instruments was from weak to substantial. A higher prevalence of pronated foot is expected in children with DS, due to specific characteristics such as ligament laxity and hypotonia, which generates a collapse of the plantar arch caused by muscle weakness. Thus, such results are in agreement with the literature [14-17].

In children with ND, the highest prevalence of pronated feet is probably related to the development of the medial longitudinal arch with growing age. As the age increases, the incidence of flat feet decreases $[11,18]$. According to Volpon [18], there is a great variation of the longitudinal arch in childhood, mainly up to 4 years old, as the development of this arch is not well established at this age. Souza, João, and Sacco [19] report that foot development is related to the plantar arch formation. These authors argue that changes in the plantar arch can alter the foot functionality, as well as the entire posture. In addition, they report the physiological presence of flat feet in healthy children, according to the measurement of the plantar arch. Lin et al. [20] noticed in their study a progressive increase of the plantar arch with increasing age. These authors related the increased plantar arch to the child's developmental progress, which is closely related to weight, height, the presence or absence of ligament laxity, and whether or not they perform physical activity. Thus, the participants of this study, being in the age group from 4 to 5 yearsold, are still in the stage of development of the plantar arch, which might explain the high prevalence of pronated foot in the children of the ND group.

The instruments used in this study are often used for evaluation in the physical therapist's clinical practice. According to Harris et al. [5], the radiological examination is essential for diagnosing pediatric feet deformities such as flat feet, as well as for allowing comparison with the time of progression and evaluation of therapeutic results. In their study, Prado Júnior, Nery and Bruschini [21] verified the occurrence of feet abnormalities in 320 asymptomatic children of both sexes in the age group from 7 to 13 years old, through general clinical examination, gait, podogram and radiographic examinations in three incidences, by measuring several angles, including the calcaneus inclination angle. In this study, one could detect that $6.6 \%$ of the sample had flat feet, $11.8 \%$ had cavus feet, with a predominance of flat feet for males and cavus ifor females [21].

Although radiography is considered the gold standard for foot type classification, this instrument is less accessible to the physical therapist due to the need for another health professional to perform it, in addition to exposing the individual to radiation. In contrast, the baropodometer and the SAPO are more accessible, being widely used for foot evaluation.

Several authors have used baropodometry as a method to assess the distribution of plantar pressures [22-24]. In the study of Molinari and Massuia [16], the static biomechanical behavior of the posture and the plantar support of children with obese and nonobese DS were analyzed through baropodometry, resulting in a higher prevalence of pronated feet in both groups, being $90 \%$ in the obese and $60 \%$ in the non-obese. Different authors have used plantar impression images to trace lines and identify the anatomical regions of the foot [25], and used the measurements of the foot regions to classify them as normal, flat, or cavus $[12,16,24]$, corroborating with what was done in this study.

Baropodometry is part of a set of diagnostic resources for feet assessment that the physiotherapist has and should not be forgotten [9, 26]. Therefore, baropodometry has proven to be an effective method for assessing plantar pressure distribution, performing an objective, quantitative, and 
indispensable examination in the analysis of plantar pressure and distribution, as well as comparing and measuring pressures at different points in the plantar region $[9,26]$. This equipment allows for analyzing and monitoring the clinical evolution and physiotherapeutic treatment $[8,27]$.

The SAPO is an instrument that has been used for postural evaluation from the angles provided, according to the pre-established anatomical points in its protocol. Bio-photogrammetry has become an alternative for the quantitative evaluation of asymmetries in postural assessment, making its data more reliable than those obtained by visual observation, giving credibility to clinical physiotherapy and reliability to rehabilitation research [7, 28].

Despite the increasing number of studies using bio-photogrammetry [29-31], there is still no standardization of the angles used to verify certain postural changes, as well as few studies that verify the reliability and reproducibility of the postural evaluation programs used, which difficults the comparison between studies and the validation of results found.

There was weak to moderate concordance among the evaluations transmitted by the three instruments, thus, showing no agreement between them. Although the three instruments are proposed to measure foot alignment, there is still no consensus in the literature on which is the ideal method for the evaluation and classification of foot types [11]. The instruments used in this study should be used in a complementary way in clinical practice, as they provide different and complementary information about foot alignment.

At least $80 \%$ of the general population have foot changes that can be corrected through an appropriate assessment [32]. Therefore, the clinical significance of flat feet should not be underestimated. The flat foot should not be seen only as a static ankle problem, but also as an abnormality of the lower limbs functional dynamics [20].

As limitations of this study, one can mention the small number of participants from each group. Despite this, it was possible to perform concordance analyzes between the instruments in an adequate and reliable manner. In addition, all children with DS, in the studied age group, who were attended at the main institutions of the city were invited to participate in the study.

\section{Conclusion}

Children with DS and ND participating in this study, in the age group from 2 to 5 years old, presented a higher prevalence of pronated feet. Possibly, the justifications for such higher prevalence are different between the groups, according to the bio-mechanical particularities of each one. Results obtained in this study allow us to infer there are differences in the evaluation of plantar pressure distributions in standing posture between the Baropodometer, SAPO, and Radiography, and the instruments should be used in a complementary way since they measure different aspects of foot alignment. However, further studies are still needed for the evaluation of plantar pressures by these three instruments in children in this age group due to the paucity of studies found.

\section{References}

1. Bull MJ, Comittee on Genetics. Health supervision for children with Down syndrome. Pediatrics. 2011;128(2):393-406.

2. Ministério da Saúde do Brasil. Diretrizes de Atenção à Pessoa com Síndrome de Down. Brasília (DF): Ministério da Saúde; 2013. 60 p.

3. Bravo-Valenzuela NJM, Passarelli MLB, Coates MV. Growth charts in children with Down syndrome: a systematic review. Rev Paul Pediatr. 2011;29(2):261-9.

4. Araujo AGS, Scartezini CM, Krebs RJ. Analysis of the gait in children bearers Down Syndrome and normal children age of 2 to 5 years. Fisioter Mov. 2007;20(3):79-85.

5. Harris EJ, Vanore JV, Thomas JL, Kravitz SR, Mendelson SA, Mendicino RW, et al. Diagnosis and treatment of pediatric flatfoot. J Foot Ankle Surg. 2004;43(6):341-73.

6. Pease J. Guidelines on best practice in the x-ray imaging of children [book review]. Radiography. 1999;5(2):119. Review of: Cook JV, Pettett A, Shah K, Pablot S, Kyriuo J, Fitzgerald M. Guidelines on best practice in the x-ray imaging of children. London: St George's Healthcare Radiological Protection Centre; 1999. 
7. Iunes DH, Castro FA, Salgado HS, Moura IC, Oliveira AS, Bevilaqua-Grossi D. Intra and inter-rater reliability and repeatability of postural evaluation by photogrammetry. Rev Bras Fisioter. 2005;9(3):327-34.

8. Baumfeld D, Baumfeld T, Rocha RL, Macedo B, Raduan F, Zambelli R, et al. Reliability of baropodometry on the evaluation of plantar load distribution: a transversal study. Biomed Res Int. 2017;2017:5925137. [cited 2019 Jan 21]. Available from: https://www.hindawi. com/journals/bmri/2017/5925137/

9. Mattos HM, Pryzsiezny WL. Baropodometric analysis of foot influence on posture. Rev Ter Man. 2004;3(1):240-6.

10. Neto HP, Grecco LA, Braun Ferreira LA, Christovão TC, Duarte NA, Oliveira CS. Clinical analysis and baropodometric evaluation in the diagnosis of abnormal foot posture: A clinical trial. J Bodyw Mov Ther. 2015;19(3):429-33.

11. Uden H, Scharfbillig R, Causby R. The typically developing paediatric foot: how flat should it be? A systematic review. J Foot Ankle Res. 2017;10(37):Suppl 13047.

12. Galli M, Cimolin V, Pau M, Costici P, Albertini G. Relationship between flat foot condition and gait pattern alterations in children with Down syndrome. J Intellect Disabil Res. 2014;58(3):269-76.

13. Landis JR, Koch GG. The measurement of observer agreement for categorical data. Biometrics. 1977;33(1):159-74.

14. Pau M, Galli M, Crivellini M, Albertini G. Relationship between obesity and plantar pressure distribution in youths with Down syndrome. Am J Phys Med Rehabil. 2013;92(10):889-97.

15. Pau M, Galli M, Crivellini M, Albertini G. Foot-ground interaction during upright standing in children with Down syndrome. Res Dev Disabil. 2012;33(6):1881-7.

16. Molinari VS, Massuia FAO. Analysis of posture and foot support of children with Down syndrome considered obese. J Health Sci Inst. 2010;28(4):345-7.
17. Falotico GG, Uyeda MTL, Romano RAL, Freitas ASP, Blumetti FC, Dobashi ET, et al. Ligament and flat foot loosening in normal children. Rev Bras Ortop. 2010;45(1):25-30.

18. Volpon,JB. O pé em crescimento, segundo as impressões plantares. Rev Bras Ortop. 1993;28(4):219-23.

19. Souza PS, João SMA, Sacco ICN. Characterization of the longitudinal plantar arch of obese children using plantar print indexes. Rev Bras Crescimento Desenvolv Hum. 2007;17(1):76-83.

20. Lin CJ, Lai KA, Kuan TS, Chou YL. Correlating factors and clinical significance of flexible flatfoot in preschool children. J Pediatr Orthop. 2001;21(3):378-82.

21. Prado Junior I, Nery CAS, Bruschini S. Ocorrência de patologias podálicas em crianças assintomáticas. Folha Med. 1992;104(1/2):25-9.

22. Azevedo LAP, Nascimento LFC. Is the distribution of plantar force associated with different types of feet? Rev Paul Pediatr. 2009;27(3):309-14.

23. Cantalino JR, Mattos HM. Analysis of the footprint emitted by two different equipments. Conscientiae Saude. 2008;7(3):367-72.

24. Cantalino JR, Mattos HM. Comparison of foot types classified by certain forms of clinical evaluation. Rev Ter Man. 2006;4(16):76-81.

25. Oliveira AP, Otowicz I. Analysis of foot support and its correlation with biomechanical dysfunctions of the ilium-sacral joint. Rev Ter Man. 2004;2(3):122-7.

26. Pryzsiezny W, Formonte M, Pryzsiezny E. Study of the behavior of plantar distribution through baropodometry in individuals without physical complaints. Rev Ter Man. 2003;2(1):28-32.

27. Gomes LG, Scremim R, Souza MA, Gamba HR. Biofeedback baropodometry training evaluation: a study with children with equinus foot deformity. Conf Proc IEEE Eng Med Biol Soc. 2013;5914-7.

28. Dunk NM, Lalonde J, Callaghan JP. Implications for the use of postural analysis as a clinical diagnostic tool: reliability of quantifying upright standing spinal postures from photographic images. J Manipulative Physiol Ther. 2005;28(6):386-92. 
29. Corrêa EC, Bérzin F. Efficacy of physical therapy on cervical muscle activity and on body posture in school-age mouth breathing children. Int J Pediatr Otorhinolaryngol. 2007;71(10):1527-35.

30. Sanchez HM, Barreto RR, Baraúna MA, Corner RST, Morais EG. Postural evaluation of individuals with visual impairment through computerized biophotogrammetry. Fisioter Mov. 2008;21(2):11-20.

31. Lima LCO, Barauna MA, Sologurem MJJ, Canto RST, Gastaldi AC. Postural alterations in children with mouth breathing assessed by computerized biophotogrammetry. J Appl Oral Sci. 2004;12(3):232-7.
32. Magee DJ. Avaliação musculoesquelética. 5th ed. São Paulo: Manole; 2010. 1228 p.

Received in 04/12/2018

Recebido em 12/04/2018

Recibido en 12/04/2018

Approved in 11/12/2018

Aprovado em 12/11/2018

Aprobado en 12/11/2018 